American Journal of Applied Sciences 8 (6): 535-539, 2011

ISSN 1546-9239

(C) 2011 Science Publications

\title{
Structure of Lamellae and Chloride Cell in the Gill of Alosa Caspio Caspio (Clupeidae, Teleostei)
}

\author{
${ }^{1}$ Z. Saadatfar and ${ }^{2}$ D. Shahsavani \\ ${ }^{1}$ Department of Anatomical Science, \\ ${ }^{2}$ Department of Clinical Science, \\ School of Veterinary Medicine, \\ Ferdowsi university of Mashhad, Mashhad, Iran
}

\begin{abstract}
As a surface for respiratory gas diffusion, ion regulation and waste excretion, gill epithelium of Alosa Caspio Caspio has been investigated. Problem statement: Surely, morphological study of gill cells is the main route for giving the basic data which can be inductive for physiological and pathological investigations. Approach: Gills were removed from Alosa Caspio which is from euryhaline species and fixed in freshly prepared glutaraldehyde and osmium tetroxide. Thin sections were stained in Uranyl acetate-lead citrate and examined under LEO transmission electron microscope. Results: Flattened respiratory lamellae extend in two rows from the sides of the filaments. The pavement cell is the major cell covering the thin epithelia of lamellae, but mucous cell and chloride cell also can be seen on lamellar epithelia, however, most of them are observed in filamental epithelia. The other cell forms the wall of capillaries in lamellae is Pillar cell. Chloride cells which are as single cells without complex junction, are surrounded by the pavement cells, have high number of large mitochondria and extensive membranous tubular system, with a free and smooth surface. There is one type of chloride cell with a light cytoplasm. Conclusion: The main ultrastructure aspects of the major cells are similar in teleosts, although some features such as the localization of chloride cell on lamellae, one type of cell, small crypts and the smooth surface are special features of this cell in Alosa Caspio that resemble this cell to freshwater species.
\end{abstract}

Key words: Lamellae cells, chloride cell, gill epithelium, Alosa Caspio Caspio, electron microscope

\section{INTRODUCTION}

Fish gills are a pretty complex structure and perform a variety of physiological functions in adult fish including respiratory gas exchange, ion and water balance, excretion of nitrogenous wastes and the maintenance of acid-base balance (Snow et al., 2008; Goss et al., 1998; Carmona et al., 2004). Gills are made up of filaments attached to a rigid gill arch. The arches are hollow and have arteries inside them that contain blood low in oxygen. These arteries branch into small arteriole that runs inside the filaments. Each filament has many lamellae to increase surface area. Tiny capillaries branch off of the arterioles and carry the blood to inner surface of the lamellae. The multilayered filament is largely involved in ion exchange and the bilayered lamellar epithelium involved in gas exchange. Many studies have described the morphological and functional characteristics of gill epithelial cells. Because of the reported variability in the position and morphological modifications of some of these cells as chloride cells (Franklin, 1990; Perry et al., 1996) and also since many physiological processes take place in the gills, disturbance of this organ comprises the survival of fish and the gills represent an appropriate indicator for environmental contamination (Galbrand et al., 2006). To our knowledge, there are no published studies on the normal structure of gills of Alosa Caspio. Thus the purpose of this study was to describe normal ultra structural morphology of most important cells in the lamellae of this species to be as a basis for further histological studies. The Alosa Caspio is an important endemic species of fish, owing to its tolerance to a wide range of salinities, it is a euryhaline species.

\section{MATERIALS AND METHODS}

In this study 5 specimens of Alosa Caspio from south of Caspian Sea were used (body weight ranging

Corresponding Author: Z. Saadatfar, Department of Anatomical Science, School of Veterinary Medicine,

Ferdowsi university of Mashhad, Mashhad, Iran 
between $90-110 \mathrm{gr}$, body length $28-30 \mathrm{~cm}$ ). The gills were dissected out and washed with a Saline solution $(0.9 \% \mathrm{Nacl})$. They were fixed in $10 \%$ buffered formaldehyde solution ( $\mathrm{pH}$ 7.3). Samples were dehydrated in a graded series of ethanol and embedded in paraffin wax. Tissue blocks were cut into $5 \mu \mathrm{m}$ thickness and were stained with H\&E and PAS for light microscope. Small samples of gills also were fixed in $2.5 \%$ glutaraldehyde in buffer ( $\mathrm{pH} 7.0)$ and post fixed in Osmium tetroxide and then dehydrated in a graded series of ethanol. The small pieces were embedded, obtained semithin sections (200nm thick) from the blocks and stained with toluidine blue, they were used to select areas for thin sectioning. They were stained with Uranile acetate and lead citrate and then photographed with a LEO transmission microscope.

\section{RESULTS}

The gills of Alosa Caspio Caspio as other teleosts consist of four holobranchs on every side of opercular cavities. Holobranchs has two rows of branchial filaments and branchial lamellae radiates out from dorsal and ventral of each filament. Two types of epithelium cover the gill filament and lamellae. The filaments are lined by a stratified epithelium and lamellae are covered by a thin epithelium.

The gill filament composed of three major cells, mucous cells, pavement cells and chloride cells. Branchial lamellae consist of capillary core covered by thin epithelia and basement membrane interposed between capillary and epithelium. The most important cells in this epithelium were pavement cell, chloride cell, mucous cell and pillar cell (Fig. 1).

Pavement cells are the most abundant cell type of filament epithelium with small electondence vesicles in the cytoplasm of the most pavement epithelial cells and there is infolding protrusion and microridges covered with a thick coat on the surface of these cells (Fig. 2). Pavement cells in lamellae have a polygonal shape with a larger surface area to pavement cells of filaments. Their nucleus is elongated and euchromatin with a cytoplasm contains small mitochondria and developed Golgi complex. They are joined by interdigitations of lateral cell membrane and tight junctions (Fig. 3).

Chloride cells (mitochondrial rich cells) are found mainly in the interlamellar space especially at the base of areas where lamellar platelets emerged. They are ovoid to elongated cells with basal nucleus. They have an abundant cytoplasm with many mitochondria and an extensive network of tubules and vesicles. They have no tight junctions with adjacent chloride cells. In most of cells the surface is free and without invagination, but in some cells the mucosal surface is below the pavement cells and produce small invagination. In this species the chloride cells are ultrastructurally as light cells with free ribosome, large mitochondria and developed tubule-vesicular system (Fig. 4). The basolateral tubular system is less developed and they have a close contact with mitochondria. There are also chloride cells with clear cytoplasm without mitochondria and tubular system (Fig. 5). It must be noticed that a few chloride cell also can be identified in the lamellar epithelia.

Mucous cells are oval in shape and located in the uppermost layer of epithelium, with a basally located nucleus and a large amount of secretory granules that fill the apical cytoplasm; the granules show a high electronic density. It has positive reaction to PAS stain. On semithin sections, they stain metachromatically with toluidine blue (Fig. 1 and 6).

Pillar cells are endothelial cells of blood space in lamellae. Their position is perpendicular to the axis of lamellae with small nuclei in the center of cells. They join with their cytoplasmic projections and by a tight junction to form the wall of capillaries (Fig. 6).

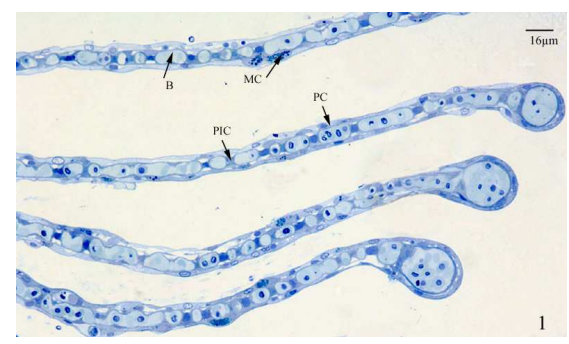

Fig. 1: Toluidine blue staining of semithin sections in gills of Alosa Caspio. B, blood channel; MC, Mucous cell; PIC, pillar cell; PC, pavement cell

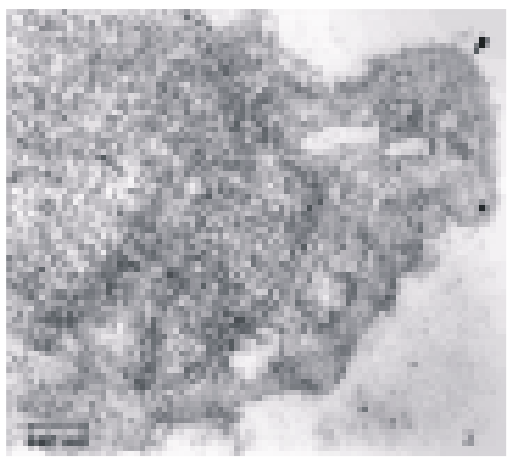

Fig. 2: Transmission electron micrographs of pavement cell with euchromatin nucleus $(\mathrm{N})$ and microridges (arrowhead) covered by mucoid material 
Am. J. Applied Sci., 8 (6): 535-539, 2011

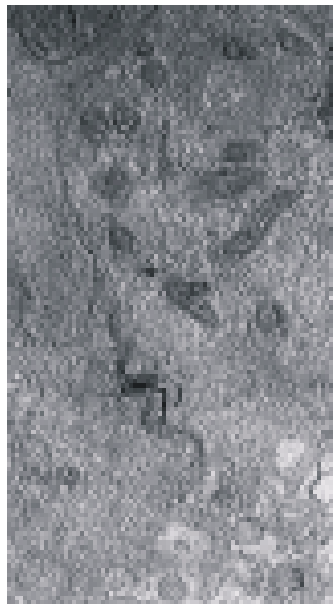

Fig. 3: Transmission electron micrographs of pavement cell. Gc, Golgi complex; m, mitochondria; J, junctions between pavement cells

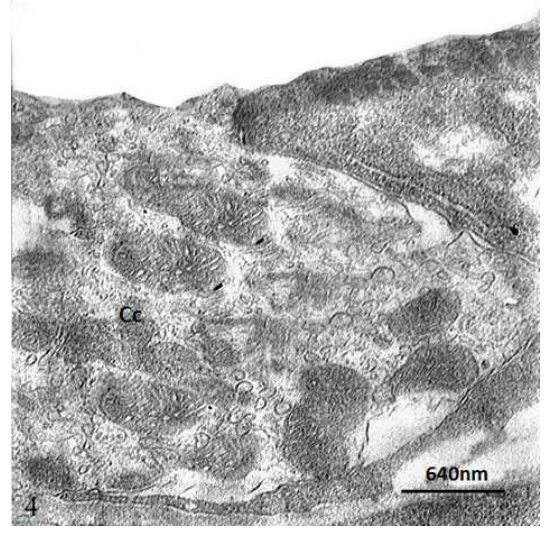

Fig. 4:Transmission electron micrograph of chloride cell in Alosa Caspio. No crypt in apical surface. Note to Great abundance of mitochondria and development of tubular network

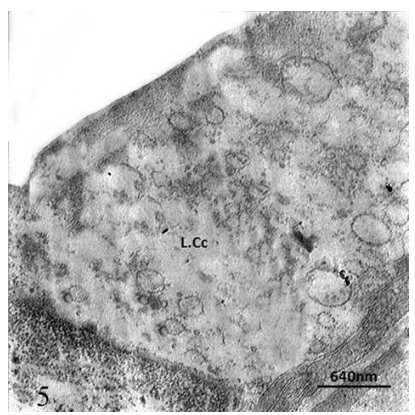

Fig. 5: Transmission electron micrograph of chloride cell with a clear cytoplasm withought mitochondria and tubular system

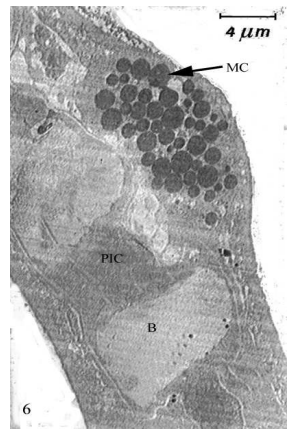

Fig. 6: Transmission electron micrographs of lamellae B, blood channel; MC, Mucous cell; PIC, pillar cell

\section{DISCUSSION}

The gill, as the main osmoregulation organ, is sensitive to environment factors and changes in salinity (Uchida et al., 2000; Bu-Olayan et al., 2008).

Pavement cell has been identified in many studies as the site of $\mathrm{Na}^{+}$uptake in filament. In these cells, the electrodense vesicles has been showed that are joined with the apical membrane and providing a mechanism for $\mathrm{H}^{+}$-ATPase (Goss et al., 1998; Wilson et al., 2000). The apical microridges of lamellar pavement cells can enhance and favor the diffusion of gases to and from water, so as an increasing area for gas exchange, can influence this process.

Chloride cells in this species were abundant on filaments, but rarely appeared on lamellae. The occurrence of lamellar chloride cells is thought to satisfy the physiological demand of ion uptake in some euryhaline teleosts (Uchida et al., 1997; Sasai et al., 1998; Hirai et al., 1999) but not in others (Laurent and Perry, 1990). The most chloride cells in this fish living in Caspian Sea showed no crypt. The crypts may play a role in the concentrations of Cations and maintenance on an ionic concentration. We failed to observe the multicellular complex in the chloride cells of Alosa Caspio. The multicellular complexity is defined in some sea water Species (Anguilla Anguilla, Solea Solea and Blennius pholis) and some freshwater teleosts (Oreochromis mossambicus, Plectoglossus altivelis and Cyprinus Carpio). This structure that is important in the process of ion exchange, According to previous studies in some fishes that live in south of Caspian Sea may be identified. The light chloride cells were the only type of this cell in Alosa Cspio and can refer to "Alphachloride cell "that are pale cells". This morphological feature has been reported in euryhaline fish during seawater adaptation. In these species that in freshwater adapted had two types of chloride cells, one type referred to alpha cell was pale and a second type was referred to beta cell was a darker cell. In seawater adapted after degeneration of beta chloride cells, they 
disappeared (Pisam et al., 1987) and alpha cells increased. The organization and location of cytoplasmic tubules, showed tubules and vesicles that often did not anastomose and were not continuous with the basolateral plasma membrane from this point it has resembled the features of freshwater that basolateral tubular system often is less developed (Pisam et al., 1987). The cells without mitochondria and tubular system can be the initial stage during the lifetime of the chloride cells.

The frequency and existence of mucous cell and a mucous layer can be affected by aquatic milieu. It also as a protective layer forms a barrier against pathogens and also diffusion of ions from gills to environment that is important in many species. The mucus produced is $\mathrm{PAS}^{+}$and it is formed from neutral mucosubstances that have a protective role. In the previous studies, it showed changes in electrodensity of granules in different conditions from salinity, so in high-salinity conditions they were clear and in freshwater environment they showed high electronic density. Although the significance of the changes is not known, the granules have been showed to join with the apical membrane to provide a mechanism for recovery of $\mathrm{H}^{+}$ATPase (Carmona et al., 2004).

\section{CONCLUSION}

According to this study, the different cell types on the gills of Alosa Caspio are similar to many other teleosts. However, some peculiarities associated with ultrastructure of chloride cell in this euryhaline species of Caspian Sea (brackish water milieu) have more similar to freshwater species.

\section{ACKNOWLEDGMENT}

The researchers thank central laboratory of Ferdowsi University of Mashhad, for processing the specimens.

This study was supported by a grant from Ferdowsi University (project 1479).

\section{REFERENCES}

Bu-Olayan, A.H., B.V. Thomas and S.M.H. Hosseini, 2008. Trace metals co-toxicity in hard body structures of Liza klunzingeri (Mugilidae: Perciformes)) mullet fish. (Technical report). Am. J. Environ Sci., 4: 326-331. DOI: 10.3844/ajessp.2008.326.331

Carmona, R., M. Garcia, G.A. Sanz, A. Domezain and M.V. Ostos-Garrido, 2004. Chloride cells and pavement cells in gill epithelia of Acipenser Naccarii: Ultrastructural modifications in seawater-acclimated specimens. J. Fish. Biol., 64: 553-566. DOI: 10.1046/j.1095-8649.2003.00321
Franklin, G.E., 1990. Surface ultrastructural changes in the gills of sockeye salmon (teleostei: Oncorhynchus nerka) during seawater transfer: Comparison of successful and unsuccessful seawater adaptation. J. Morphol., 206: 13-23. DOI: $10.1002 /$ jmor.1052060103

Galbrand, C., I.G. Lemieux, A.E. Ghaly, R. Cote and M. Verma, 2006. Water quality assessment of a constructed Wetland treating landfill leachate and industrial park Ranoff. Am. J. Environ Sci., 2: 4959. DOI: 10.3844/ajessp.2006.49.59

Goss, G.G., S.F. Perry, J.N. Fryer and P. Laurent, 1998. Gill morphology and acid-base regulation in freshwater fishes. Comp. Biol. Physiol., 119: 107115. DOI: 10.1016/S1095-8433(97)00401-7

Hirai, N., M. Tagawa, T. Kaneko, T. Seikai and M. Tanaka, 1999. Distributional changes in branchial chloride cells during freshwater adaptation in Japanese sea bass Lateolabrax japonicas. Zool. Sci., 16: 43-49. DOI: 10.2108/zsj.16.43

Laurent, P. and S.F. Perry, 1990. Effects of cortisol on gill chloride cell morphology and ionic uptake on the freshwater trout, Salmo gairdneri. Cell. Tiss. Res., 259: 429-442. DOI: 10.1007/BF01740769

Perry, S.F., G.G. Goss and J.C. Fenwick, 1996. The interrelationship between gill chloride cell morphology and calcium uptake in freshwater teleost. Fish. Physiol. Zool., 69: 1419-1441. http://www.jstor.org/stable/30164267

Pisam, M., A. Caroff and A. Rambourg, 1987. Two types of chloride cells in the Gill epithelium of a freshwater-adapted euryhaline fish: Lebistes reticulatus, their modificationsduring adaptations to sea water. Am. J. Anat., 179: 40-50. DOI: 10.1002/aja.1001790106

Sasai, S., T. Kaneko, S. Hasegawa and K. Tsukamoto, 1998. Morphological alteration in two types of gill chloride cells in Japanese eels (Anguilla japonica) during catadromous migration. Can. J. Zool., 76: 1480-1487. DOI: $10.1139 / \mathrm{cjz}-76-8-1480$

Snow, A.M., A.E. Ghaly and A. Snow, 2008. A comparative assessment of hydroponically grown cereal crops for the purification of aquaculture wastewater and the production of fish feed. Am. J. Agri. Biol. Sci., 3: 364-378. DOI: 10.3844/ajabssp.2008.364.3

Uchida, K., T. Kaneko, A. Yamaguchi, T. Ogasawara and T. Hirano, 1997. reduced hypoosmoregulatory ability and alterration in gill chloride cell distribution in mature chum salmon (Oncorhynchus Keta) migrating upstream for spawning. Marine. Biol., 129: 247-253. DOI: 10.1007/s002270050165 
Uchida., K., T. Kaneko, H. Miyazaki, S. Hasegawa and T. Hirano, 2000. Excellent salinity tolerance of mozambique tilapia (Oreochromis mossambicus): Elevated Chloride cell activity in the branchial and opercular epithelia of the fish adapted to concentrated seawater. Zool. Sci., 17: 149-160. DOI: $10.2108 / z s j .17 .149$
Wilson, J.M., P. Laurent, B.L Tufts, D.J. Benos and M. Donowitz et al., Randall, 2000. $\mathrm{NaCl}$ uptake by the branchial epithelium in freshwater teleost fish. An immunological approach to ion-transport protein localization. J. Exp. Biol., 203: 2279-2296. PMID: 10887067 